\title{
Anti-proliferative effect of methanolic extract of Gracilaria tenuistipitata on oral cancer cells involves apoptosis, DNA damage, and oxidative stress
}

Chi-Chen Yeh ${ }^{1}$, Jing-long Yang ${ }^{2}$, Jin-Ching Lee ${ }^{3}$, Chao-Neng Tseng ${ }^{1,4}$, Ya-Ching Chan ${ }^{4}$, You-Cheng Hseu ${ }^{5}$, Jen-Yang Tang ${ }^{6,7}$, Li-Yeh Chuang ${ }^{8}$, Hurng-Wern Huang ${ }^{9}$, Fang-Rong Chang ${ }^{1 *}$ and Hsueh-Wei Chang ${ }^{1,4,10^{*}}$

\begin{abstract}
Background: Methanolic extracts of Gracilaria tenuistipitata (MEGT) were obtained from the edible red algae. Previously, we found that water extract of G. tenuistipitata was able to modulate oxidative stress-induced DNA damage and its related cellular responses.

Methods: In this study, the methanol extraction product MEGT was used to evaluate the cell growth inhibition in oral cancer cells and its possible mechanism was investigated.

Results: The cell viability of MEGT treated Ca9-22 oral cancer cell line was significantly decreased in a doseresponse manner $(p<0.05)$. The sub-G1 population and annexin $V$ intensity of MEGT-treated Ca9-22 cancer cells were significantly increased in a dose-response manner $(p<0.0005$ and $p<0.001$, respectively). The $\gamma \mathrm{H} 2 \mathrm{AX}$ intensities of MEGT-treated Ca9-22 cancer cells were significantly increased in a dose-response manner $(p<0.05)$. The reactive oxygen species (ROS) and glutathione (GSH)-positive intensities of MEGT-treated Ca9-22 oral cancer cells were significantly increased and decreased, respectively, in a dose-response manner $(p<0.05)$. The $\operatorname{DiOC}_{2}(3)$ intensity for mitochondrial membrane potential (MMP) of MEGT-treated Ca9-22 cancer cells was significantly decreased in a dose-response manner $(p<0.05)$.
\end{abstract}

Conclusions: These results indicated that MEGT had apoptosis-based cytotoxicity against oral cancer cells through the DNA damage, ROS induction, and mitochondrial depolarization. Therefore, MEGT derived from the edible algae may have potential therapeutic effects against oral squamous cell carcinoma (OSCC).

Keywords: Red algae, Oral cancer, Apoptosis, Y-H2AX, ROS, Mitochondrial membrane potential, Glutathione

\section{Background}

Oral squamous cell carcinoma (OSCC), the sixth most common cancer worldwide [1], is characterized by high morbidity and mortality rates. The poor prognosis for OSCC [2] is mainly due to its poor response to chemotherapy [3]. Therefore, drug discovery for anti-OSCC therapy remains challenging.

\footnotetext{
* Correspondence: aaronfrc@kmu.edu.tw; changhw@kmu.edu.tw ${ }^{1}$ Graduate Institute of Natural Products, College of Pharmacy, Kaohsiung Medical University, Kaohsiung, Taiwan

${ }^{4}$ Department of Biomedical Science and Environmental Biology, Kaohsiung Medical University, Kaohsiung, Taiwan

Full list of author information is available at the end of the article
}

Natural products [4-8], especially from marine sources [9-12], offer an abundance for drug development to treat many types of cancer. Algae contain many bioactive primary and secondary metabolites $[13,14]$ and represent about $9 \%$ of marine biomedical compounds [15]. Among them, the bioactive compounds of the genus Gracilaria had been summarized [16,17] and mainly classified by water [18-20] and ethanol/methanol [21-23] extractions. Most of these studies focus on health promoting effects, such as anti-inflammatory, anti-hypercholesterolemic, antioxidative, and antimicrobial properties rather than on cancer therapy.

\section{Biomed Central}

(C) 2012 Yeh et al.; licensee BioMed Central Ltd. This is an Open Access article distributed under the terms of the Creative Commons Attribution License (http://creativecommons.org/licenses/by/2.0), which permits unrestricted use, distribution, and reproduction in any medium, provided the original work is properly cited. 
The Gracilaria algae is inexpensive in Taiwan because it has been cultivated since 1961 [24], and therefore, is an abundant resource for research purposes. In our previous work [25], water extracts of G. tenuistipitata demonstrated a potential protective effect from hydrogen peroxideinduced DNA damage. However, extraction methods may influence the biological effects for some natural products including soy products [26]. Recently, many ethanolic or methanolic extracts of natural products were found to possess antiproliferative effects in cancer; such as Njavara ethanolic extracts for glioma cells [27], Cassia tora methanolic leaf extracts for HeLa cells [28], Olea europaea ethanolic extracts for leukemic cells [29], Plocamium telfairiae methanolic extracts for colon cancer cells [30], and Indigofera linnaei Ali methanolic extracts for tumor cells [31]. Accordingly, the biological effects for methanolic extracts of G. tenuistipitata (MEGT) were evaluated in this study.

In this study, we propose that MEGT has the potential to modulate the cell proliferation of OSCC. To test this hypothesis, the anticancer potential against the human OSCC cancer cells (Ca9-22) was explored in terms of the cell viability and the alterations of cell cycle, apoptosis, ROS, GSH content, and mitochondrial membrane potential to determine the possible mechanism of action.

\section{Methods}

\section{Raw materials}

The seaweed Gracilaria tenuistipitata was collected in spring of 2009 from a culture farm at Kouhu beach, Yunlin County, Taiwan, and was delivered to the laboratory at $0^{\circ} \mathrm{C}$. In the laboratory, the algae were washed with running tap water to remove epiphytes and encrusting material, soaked in distilled water twice, and then lyophilized. The dried sample was pulverized and passed through 60-mesh sieve. The lyophilized sample was then ground to a fine powder and stored at $-40^{\circ} \mathrm{C}$.

\section{Sample extraction}

The dried samples (50 g) were immersed in $250 \mathrm{ml}$ methanol three times and were immediately extracted with $1000 \mathrm{ml}$ of $99.9 \%$ methanol in a mechanical shaker at room temperature for $24 \mathrm{~h}$. Subsequently, the extract of methanol solution was filtered with Whatman No. 1 filter paper three times. The filtered solution was then collected and evaporated to dryness at $40 \pm 2^{\circ} \mathrm{C}$ in a rotary evaporator (Buchi Laboratoriums-Technik, Switzerland). The dry extract was stored in a sealed container at $-40^{\circ} \mathrm{C}$ until use.

\section{Cell cultures}

The human OSCC cancer cell line, Ca9-22 [32,33], was cultured in DMEM medium (Gibco, Grand Island, NY, USA) and supplemented with $10 \%$ fetal bovine serum (FBS), $100 \mathrm{U} / \mathrm{ml}$ penicillin, $100 \mu \mathrm{g} / \mathrm{ml}$ streptomycin, $0.03 \%$ glutamine and $1 \mathrm{mM}$ sodium pyruvate. The cells were incubated at $37^{\circ} \mathrm{C}$ in a humidified atmosphere containing $5 \% \mathrm{CO}_{2}$.

\section{Cell viability assay}

MEGT was dissolved in DMSO and added to medium to make the final concentration of DMSO less than $1 \%$. Cell proliferation was determined by the WST-1 kit (Roche) [34]. Cells were plated at a density of $1 \times 10^{5}$ cells/well in a 96-well cell culture plate and treated with methanolic extract at doses of $0.1,0.25,0.5,1 \mathrm{mg} / \mathrm{ml}$ for $24 \mathrm{~h}$. After incubation, the WST-1 proliferation reagent (Roche) was added to cells (10 $\mu \mathrm{l}$ per well) and continued to incubate for $1-2 \mathrm{~h}$ at $37^{\circ} \mathrm{C}$. Plates were checked visually by comparing the colors of the wells with or without MEGT-treated cells.

\section{Cell cycle distribution}

Cells were treated with a solvent vehicle of $0.1,0.25,0.5$ and $1 \mathrm{mg} / \mathrm{ml}$ of MEGT for $24 \mathrm{~h}$. After trypsinization, the cells were harvested, washed twice with PBS, and fixed overnight with $70 \%$ ethanol. After centrifugation, the cell pellets were stained with $10 \mu \mathrm{g} / \mathrm{ml}$ propidium iodide (PI) (Sigma, St Louis, MO, USA) and $10 \mu \mathrm{g} / \mathrm{ml}$ RNase A in PBS buffer for $15 \mathrm{~min}$ at room temperature in the dark. PI intensities were measured using a FACSCalibur flow cytometer (Becton-Dickinson, Mansfield, MA, USA) and analyzed Win-MDI software, version 2.9 (http://facs. scripps.edu/wm29w98.exe).

\section{Flow cytometry-based detection of Annexin V staining}

Annexin V staining (Pharmingen, San Diego, CA) was performed to examine the apoptosis status as previously described [35]. A total of $1 \times 10^{6}$ cells per $100-\mathrm{mm}$ petridish were treated with vehicle or increasing concentrations of MEGT for 24 h. Finally, cells were stained with $10 \mu \mathrm{g} / \mathrm{ml}$ of annexin V-fluorescein isothiocyanate (FITC) and analyzed using the FACSCalibur flow cytometer.

\section{Flow cytometry-based detection of $\mathrm{y}-\mathrm{H} 2 \mathrm{AX}$ staining}

The MEGT-treated cells were fixed in 70\% ethanol, washed twice in BSA-PBST solution (1\% bovine serum albumin and $0.2 \%$ Triton X-100 in PBS; Sigma), and incubated with $100 \mu \mathrm{l}$ of BSA-PBST solution containing $0.2 \mu \mathrm{g}$ p-Histone H2A.X (Ser 139) monoclonal antibody (Santa Cruz Biotechnology, Santa Cruz, CA, USA) overnight at $4^{\circ} \mathrm{C}$. After washing twice with BSA-PBST, cells were suspended in Alexa Fluor 488-tagged secondary antibody (Jackson Laboratory, Bar Harbor, ME, USA) at a 1:100 dilution for $1 \mathrm{~h}$. After washing twice with BSAPBST, cells were resuspended in PBS for analysis using the FACSCalibur flow cytometer. 
Flow cytometry-based detection of intracellular reactive oxygen species (ROS)

Intracellular ROS was measured using 2',7'-dichlorodihydrofluorescein diacetate (DCFH-DA) as previously described [36] with slight modification. MEGT-treated cells were washed with PBS twice and then incubated with $10 \mu \mathrm{M}$ H2DCF-DA in PBS for $30 \mathrm{~min}$ at $37^{\circ} \mathrm{C}$. Cells were harvested and washed twice with PBS. After centrifugation, cells were resuspended in PBS and immediately forwarded to analysis by the FACSCalibur flow cytometer with excitation and emission settings of 480 and $525 \mathrm{~nm}$, respectively.

\section{Flow cytometry-based detection of cellular reduced glutathione (GSH) content}

Cells $\left(8 \times 10^{5}\right)$ were cultured in 60-mm tissue-culture dishes for $24 \mathrm{~h}$. The culture medium was replaced with new medium when the cells were $80 \%$ confluent. After MEGT treatments, the cells were incubated with $5 \mu \mathrm{M}$ CMF-DA for $20 \mathrm{~min}$ at $37^{\circ} \mathrm{C}$ in the $\mathrm{CO}_{2}$ incubator. The CMF fluorescence is directly related to the intracellular GSH level. After CMF-DA staining, the cells were washed with PBS, collected by centrifugation, and then measured with the FACS-Calibur flow cytometer.

\section{Flow cytometry-based detection of mitochondrial membrane potential}

Mitochondrial membrane potential (MMP) was measured using a MitoProbe ${ }^{\mathrm{TM}} \mathrm{DiOC}_{2}(3)$ assay kit (Invitrogen, San Diego, CA, USA). MEGT-treated Ca9-22 cells were suspended in $1 \mathrm{ml}$ of warm PBS at approximately $1 \times 10^{6}$ cells $/ \mathrm{ml}$, loaded with $5 \mu \mathrm{l}$ of $10 \mu \mathrm{M} \mathrm{DiOC} 2(3)$, and incubated at $37^{\circ} \mathrm{C}, 5 \% \mathrm{CO}_{2}$, for 20 to $30 \mathrm{~min}$. Cells were then harvested, washed and resuspended in PBS and analyzed immediately using flow cytometry assay with excitation and emission settings of 488 and $525 \mathrm{~nm}$, respectively.

\section{Statistical analysis}

All data are presented as means \pm S.E. Comparison between experimental groups was assessed by one-way ANOVA with Tukey's HSD Post Hoc Test using the software JMP ${ }^{\circledR}$ 9. Differences between treatments of different concentrations containing the same letter are not significant.

\section{Results}

Cytotoxicity effects of MEGT-treated Ca9-22 oral cancer cells

In the WST-1 assay (Figure 1), the relative cell viability at various concentrations of $\operatorname{MEGT}(0,0.01,0.25,0.5$ and $1 \mathrm{mg} / \mathrm{ml}$ ) after $24 \mathrm{~h}$ were $100.0 \pm 2.1,106.1 \pm 4.3$, $55.5 \pm 4.1,37.4 \pm 2.5,14.2 \pm 1.1(\mathrm{n}=5)$. The cell viability of MEGT-treated Ca9-22 oral cells significantly

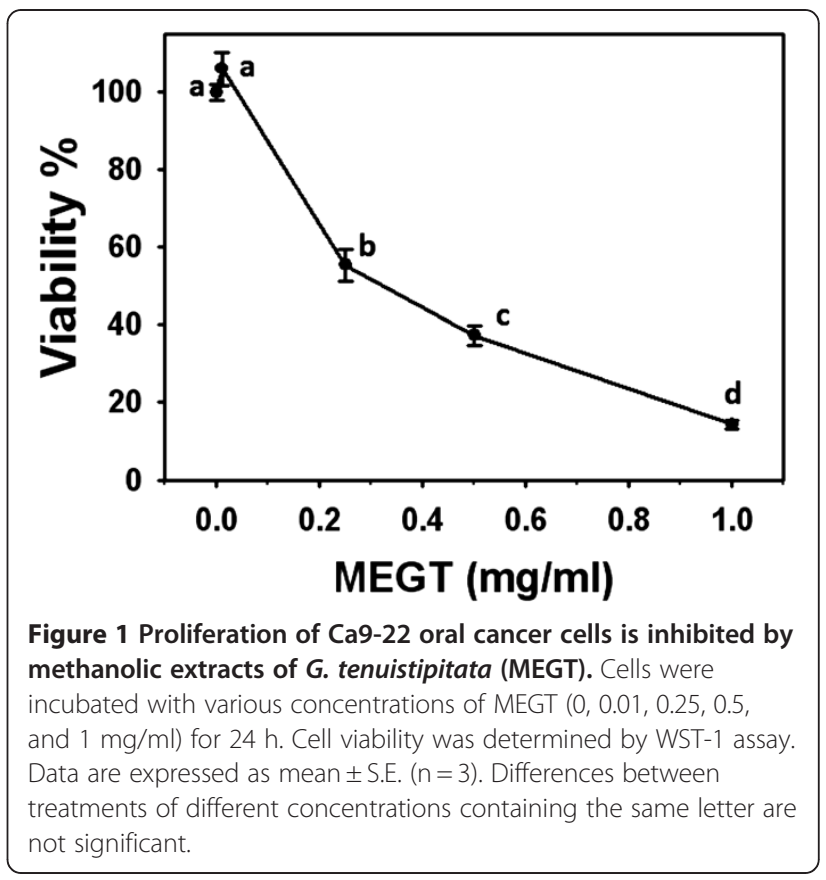

decreased in a dose-response manner $(p<0.05)$. The $\mathrm{IC}_{50}$ value of the MEGT-treated Ca9-22 oral cancer cells at $24 \mathrm{~h}$ was $0.326 \mathrm{mg} / \mathrm{ml}$.

Changes of cell cycle distribution in MEGT-treated Ca9-22 oral cancer cells

The G1 percentages were significantly increased at the concentrations from 0 to $0.25 \mathrm{mg} / \mathrm{ml} \mathrm{MEGT} \mathrm{leading} \mathrm{to}$ G1 arrest (Figure 2). Concentrations greater than $0.5 \mathrm{mg} / \mathrm{ml}$ significantly decreased the G1 percentages of cells $(p<0.0005)$. In addition, the sub-G1 populations of MEGT-treated cells were slightly increased at a dose of $0.25 \mathrm{mg} / \mathrm{ml}$, moderately increased at $0.5 \mathrm{mg} / \mathrm{ml}$, and dramatically increased at $1 \mathrm{mg} / \mathrm{ml}$. This MEGT-induced sub-G1 accumulation of Ca9-22 oral cancer cells was significantly increased in a dose-response manner $(p<0.0005)$.

\section{Apoptosis induction of MEGT-treated Ca9-22 oral cells}

To further examine whether MEGT-induced sub-G1 accumulation of Ca9-22 oral cancer cells involves apoptosis, the flow cytometry based-annexin $\mathrm{V}$ measurement was performed. In Figure $3 \mathrm{~A}$, the percentages and profiles of annexin $\mathrm{V}$-positive staining were displayed for the treatments with vehicle control or $0.1,0.25,0.5$ and $1 \mathrm{mg} / \mathrm{ml}$ of MEGT for $24 \mathrm{~h}$. After $24 \mathrm{~h}$ MEGT treatment, the annexin $\mathrm{V}$-positive staining of Ca9-22 oral cancer cells was significantly increased in a dose-response manner $(p<0.001)$ (Figure 3$)$. 


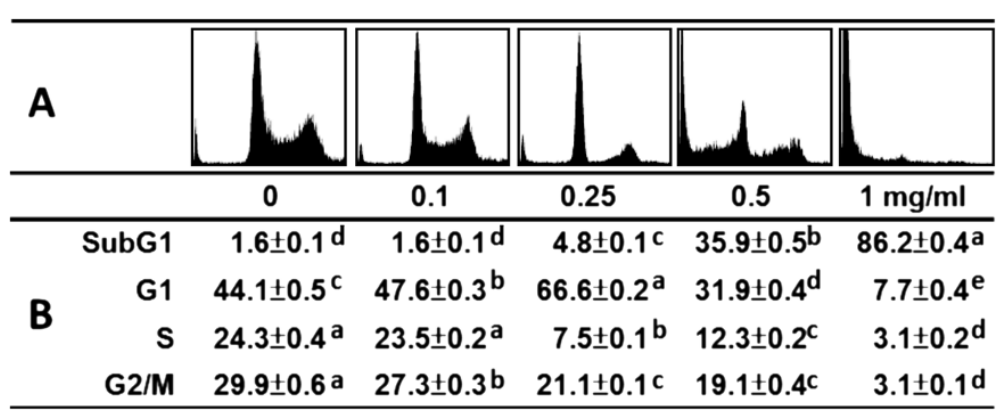

Figure 2 Methanolic extracts of G. tenuistipitata (MEGT) induces an accumulation in the sub-G1 population in Ca9-22 oral cancer cells. Cells were treated with the indicated $0,0.01,0.25,0.5$, and $1 \mathrm{mg} / \mathrm{ml}$ of MEGT for $24 \mathrm{~h}$, respectively. (A) Cell cycle profiles for MEGT-treated Ca9-22 oral cancer cells and vehicle controls at $24 \mathrm{~h}$. (B) The quantification analysis for the percentages of cell cycle stages. Data are presented as mean \pm S.E. $(n=3)$. Differences between treatments of different concentrations containing the same letter are not significant.

Induction of DNA double strand breaks in MEGT-treated Ca9-22 oral cancer cells

To evaluate whether DNA damage was involved in the MEGT-induced growth inhibition of Ca9-22 oral cancer cells, the flow cytometry based- $\gamma \mathrm{H} 2 \mathrm{AX}$ measurement was performed. The percentages and profiles of $\gamma \mathrm{H} 2 \mathrm{AX}$-positive staining were displayed for the treatments with vehicle control or $0.1,0.25,0.5$ and $1 \mathrm{mg} / \mathrm{ml}$ of MEGT for $24 \mathrm{~h}$ (Figure 4A). After $24 \mathrm{~h}$ MEGT treatment, the $\gamma \mathrm{H} 2 \mathrm{AX}$-positive staining of Ca9-22 oral cancer cells was significantly increased in a dose-response manner $(p<0.05)$ (Figure 4B).
ROS induction in MEGT-treated Ca9-22 oral cancer cells To evaluate whether ROS was involved in the MEGTinduced apoptosis of Ca9-22 oral cancer cells, the flow cytometry based-DCFH-DA assay was performed (Figure 5). The fluorescence intensities of ROSpositive staining were calculated for various concentrations of MEGT treatment with $100 \mu \mathrm{M} \mathrm{H} \mathrm{H}_{2} \mathrm{O}_{2}$ as the positive control. The percentages and profiles of ROS-positive staining of $0,0.1,0.25,5$ and $1 \mathrm{mg} / \mathrm{ml}$ MEGT for $24 \mathrm{~h}$ were calculated (Figure 5A). The ROS-positive intensity of MEGT-treated Ca9-22 oral cancer cells was significantly increased in a dose-response manner $(p<0.0001)$ (Figure $5 \mathrm{~B})$.

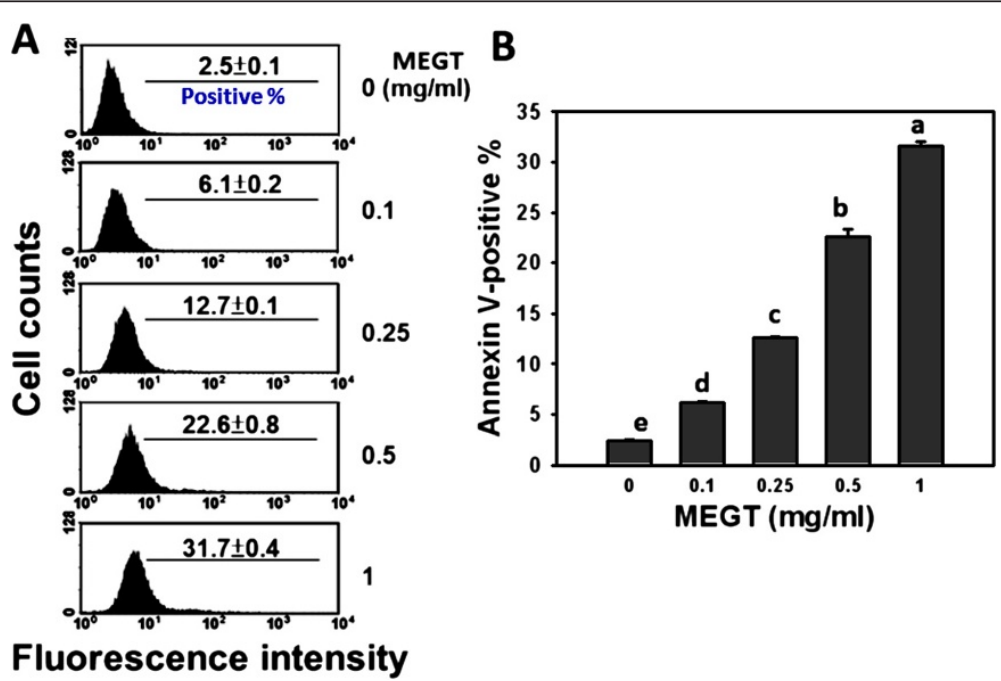

Figure 3 Methanolic extracts of G. tenuistipitata (MEGT) induced apoptosis of Ca9-22 oral cancer cells. (A) Cells treated with different concentrations (0 to $1 \mathrm{mg} / \mathrm{ml}$ ) of MEGT for $24 \mathrm{~h}$ were stained with annexin V-FITC. (B) Quantification analysis of annexin V intensity. Data are presented as mean \pm S.E. $(n=3)$. Differences between treatments of different concentrations containing the same letter are not significant. 


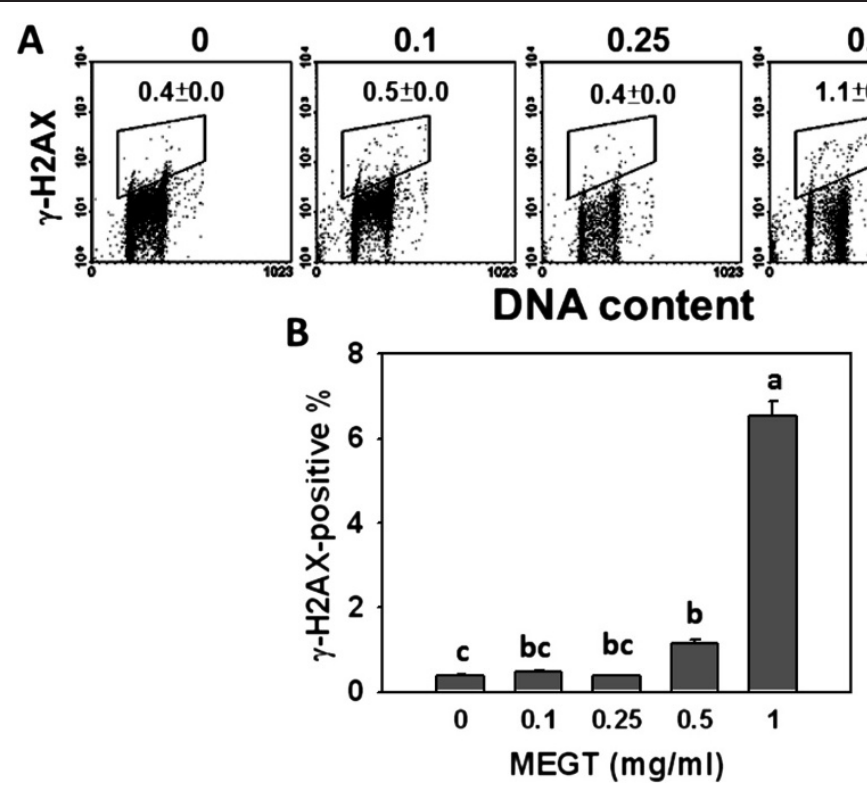

Figure 4 Methanolic extracts of G. tenuistipitata (MEGT) induced DNA double strand breaks of Ca9-22 oral cancer cells. (A) Cells treated with different concentrations ( 0 to $1 \mathrm{mg} / \mathrm{ml}$ ) of MEGT for $24 \mathrm{~h}$ were stained with $\gamma \mathrm{H} 2 \mathrm{AX}$. (B) Quantification analysis of $\mathrm{YH} 2 \mathrm{AX}$ intensity. Data are presented as mean \pm S.E. $(n=3)$. Differences between treatments of different concentrations containing the same letter are not significant.

Depletion of intracellular GSH induced by MEGT-treated Ca9-22 oral cancer cells

To evaluate whether GSH was involved in the MEGTinduced ROS change of Ca9-22 oral cancer cells, the flow cytometry based-CMF-DA assay was performed. The percentages and profiles of GSH-positive staining of $0,0.1,0.25,0.5$ and $1 \mathrm{mg} / \mathrm{ml}$ MEGT for $24 \mathrm{~h}$ were calculated (Figure $5 \mathrm{C}$ ). This revealed GSH-positive intensity
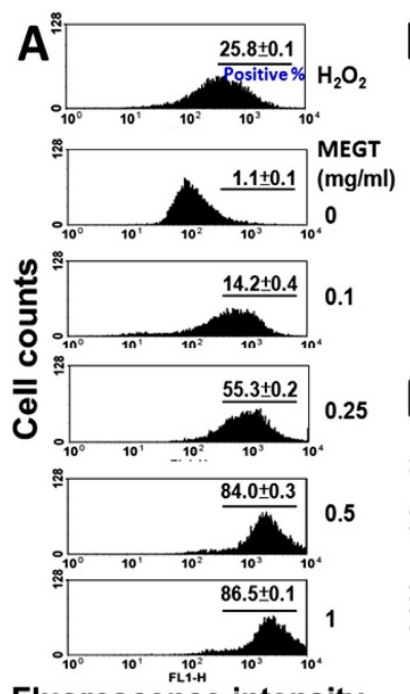

Fluorescence intensity

(ROS)
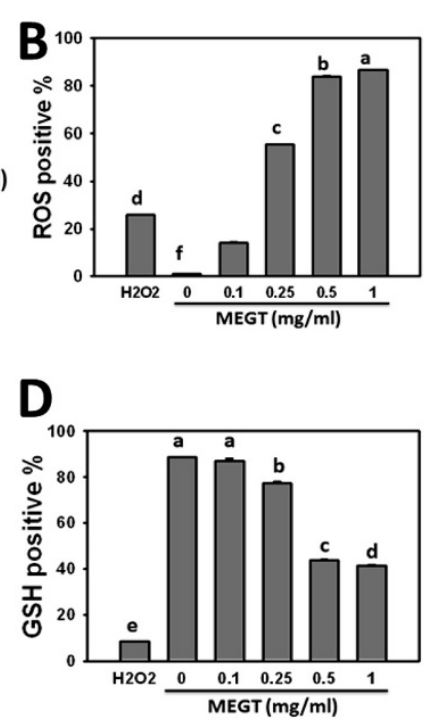

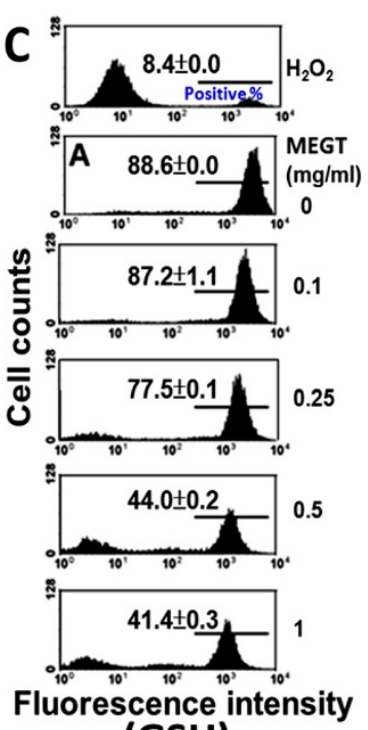

(GSH)

Figure 5 Methanolic extracts of G. tenuistipitata (MEGT) induced reactive oxygen species (ROS) changes and glutathione (GSH) depletion of Ca9-22 oral cancer cells. (A) Flow cytometry-based ROS profiles for MEGT-treated cells. Cells treated with different concentrations ( 0 to $1 \mathrm{mg} / \mathrm{ml}$ ) of MEGT and $\mathrm{H}_{2} \mathrm{O}_{2}(100 \mu \mathrm{M}$; positive control) for $24 \mathrm{~h}$. (B) Quantification analysis of ROS intensity. Data are presented as mean $\pm \mathrm{S}$. E. $(n=3)$. (C) Flow cytometry-based GSH profiles for MEGT-treated cells. Cells treated with different concentrations (0 to $1 \mathrm{mg} / \mathrm{ml}$ ) of MEGT and $\mathrm{H}_{2} \mathrm{O}_{2}(100 \mu \mathrm{M}$; positive control) for $24 \mathrm{~h}$. (D) Quantification analysis of intracellular GSH intensity. Data are presented as mean \pm S.E. $(n=3)$. Differences between treatments of different concentrations containing the same letter are not significant. 
of MEGT-treated Ca9-22 oral cancer cells was significantly decreased in a dose-response manner $(p<0.05)$ (Figure 5D).

\section{Reduction of mitochondrial membrane potential (MMP) in} MEGT-treated Ca9-22 oral cancer cells

To evaluate whether MMP was involved in the MEGTinduced ROS change of Ca9-22 oral cancer cells, the flow cytometry based-DiOC 2 (3) assay was performed. The percentages and profiles of $\mathrm{DiOC}_{2}(3)$-positive staining of $0,0.1,0.25,0.5$ and $1 \mathrm{mg} / \mathrm{ml} \mathrm{MEGT} \mathrm{for} 24 \mathrm{~h}$ were calculated (Figure 6A). This demonstrated the $\mathrm{DiOC}_{2}$ (3)-positive intensity of MEGT-treated Ca9-22 oral cancer cells was significantly decreased in a dose-response manner $(p<0.05)$ (Figure 6B).

\section{Discussion}

Many genotoxic drugs express their anticancer effects through direct or indirect DNA damage and thus resulting in cell death [37]. Therefore, many chemopreventive agents focus on targeting apoptosis-inducing pathways [38]. For example, several chemotherapeutic drugs, such as cisplatin [39], 5-fluorouracil [40], and taxol [41], have been used for head and neck cancers and are found to induce specific apoptotic pathways. Moreover, drug resistance is partly explained by the ability of cancer cells to evade apoptosis [42-44]. Accordingly, drugs with apoptosis-inducing ability in OSCC may reduce potential drug resistance.

This study shows a novel finding that MEGT has a cytotoxic effect on Ca9-22 oral cancer cells. The cell proliferation inhibiting effect of MEGT in Ca9-22 oral cancer cells is dose-dependent. The $\mathrm{IC}_{50}$ value of MEGT-treated Ca922 oral cancer cell line is $326 \mu \mathrm{g} / \mathrm{ml}(24 \mathrm{~h})$. For comparison, the reported $\mathrm{IC}_{50}$ values (treatment times) of water/ ethanol/methanol/ethyl acetate extracts for several natural product studies based on cancer cells were found in similar ranges: Moringa oleifera leaf water extract for HeLa derivative $\mathrm{KB}$ cells [45] was $150 \mu \mathrm{g} / \mathrm{ml}$ (48 h) [46]; Cassia tora methanolic leaf extract for HeLa cells was $191 \mu \mathrm{g} / \mathrm{ml}$ (48 h) [28]; Olea europaea ethanolic extract for leukemic (Jurkat) cells was $0.9 \mathrm{mg} \mathrm{dw}$ (48 h) [29]; Indigofera linnaei Ali methanolic extract for cervical, liver, breast, and colon cancer (HeLa, HepG2, MCF-7, and HT-29) cells were less than $100 \mu \mathrm{g} / \mathrm{ml}$ (72 h) [31]; and Colpomenia sinuosa, Halimeda discoidae, and Galaxaura oblongata ethyl acetate extract for liver cancer (HuH-7) cells were 112.38, 230.53, and $123.54 \mu \mathrm{g} / \mathrm{ml}(72 \mathrm{~h})$ and for leukemia (HL-60) cells were $53.35,226.35$, and $132.73 \mu \mathrm{g} / \mathrm{ml}$, respectively.

In experiments with cancer cells other than oral cancer, the incubation times differ from the $24 \mathrm{~h}$ incubation period used in this study. Accordingly, the results of lower $\mathrm{IC}_{50}$ doses obtained in these studies may be due to the longer incubation times used. In general, the treated dosage of the current developed MEGT is similar to the range of the dosage of natural product-derived extracts used in these cancer studies.

Moreover, the $\mathrm{IC}_{50}$ value of clinical chemotherapeutic drug cisplatin was $174 \mu \mathrm{g} / \mathrm{ml}(48 \mathrm{~h})$ for HeLa cells [28]. Accordingly, these results suggest that the MEGT is a potential natural product to be used as a chemotherapeutic agent as determined by its effect on Ca9-22 oral cancer cells. Moreover, more natural products with anti-oral cancer activity may be examined for their possible synergistic effects to enhance the efficiency of OSCC chemotherapy.

The possible mechanism for MEGT-induced cell growth inhibition may be partly due to apoptosis in OSCC cells demonstrated by the increases seen using sub-G1 and annexin V-staining. To further validate the role of apoptosis, the caspase signaling pathway $[47,48]$ may need to be examined. The increase of $\gamma-\mathrm{H} 2 \mathrm{AX}$-based DNA double
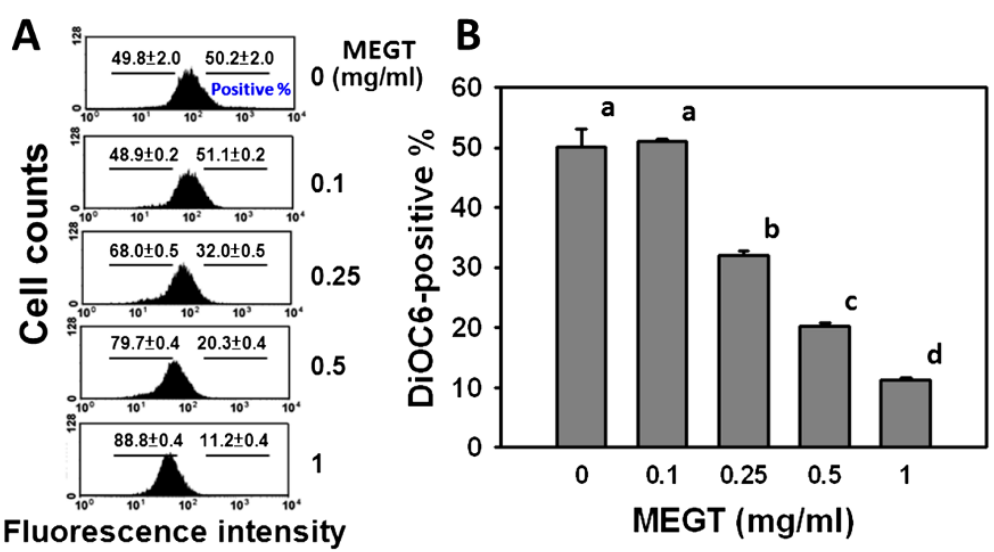

Figure 6 Methanolic extracts of G. tenuistipitata (MEGT) induced mitochondrial membrane potential (MMP) changes of Ca9-22 oral cancer cells. (A) Flow cytometry-based MMP profiles for MEGT-treated cells. Cells treated with different concentrations (0 to $1 \mathrm{mg} / \mathrm{ml})$ of MEGT for 24 h. (B) Quantification analysis of $\mathrm{DiOC}_{2}$ (3)-intensity for MMP. Data are presented as mean \pm S.E. $(n=3)$. Differences between treatments of different concentrations containing the same letter are not significant. 
strand breaks [49] under MEGT administration suggested that DNA damage is involved in MEGT-induced apoptosis. To monitor the $\gamma-\mathrm{H} 2 \mathrm{AX}$ foci [50] and the tailing degrees of the images in single cell electrophoresis (comet assay) [51] by fluorescent microscopy, the evidence of DNA damage may be further observed. Furthermore, the DNA damage response cascade and ROS signaling pathway are two of the main pathways leading to cell death $[52,53]$. DNA damage has also been reported to induce ROS generation through the H2AX-Nox1/Rac1 pathway [52]. ROS is an important mediator of apoptosis [54] and cell cycle checkpoint functions [55]. Accordingly, the MEGT-induced intracellular ROS changes were examined in OSCC cells.

Many anti-cancer drugs target cells, at least in part, by generating high levels of intracellular ROS [56,57]. In the example of brown algae, ethyl acetate extracts from Colpomenia sinuosa were reported to induce apoptosis and intracellular ROS in leukemia U937 cells [31]. Consistently, the current study demonstrated that MEGT induced the ROS in oral cancer cells in a dose-response manner.

In the study of ethyl acetate extracts from brown algae Colpomenia sinuosa [31], the research focused on the subG1 phase as an indication of apoptosis without further exploring the overall alterations in the cell cycle. In contrast, ethanol extracts of blue-green algae Aphanizomenon flosaquae displayed the G0/G1 arrest in HL-60 leukemia cancer cell lines in $24 \mathrm{~h}$ incubation [58]. Similarly, we found that the MEGT-treated Ca9-22 cells at the concentration of $0.25 \mathrm{mg} / \mathrm{ml}$ significantly increased the percentage of G1 phase cells and concurrently decreased the percentages of $S$ phase cells and cells following G2/M, supporting the hypothesis that MEGT may lead to a G1 phase arrest before apoptosis. Therefore, algal extract may elicit cell cycle arrest responses.

GSH is protective against intracellular ROS, which induces apoptosis in response to cell injury. Depletion of GSH increases susceptibility to ROS, and results in damage [59] such as DNA fragmentation [60]. Accordingly, many chemotherapeutic agents are developed by the apoptosisinducible strategy through ROS-mediated cell damage. Consistently, the ROS level of Ca9-22 oral cancer cells after MEGT treatment for $24 \mathrm{~h}$ was increased, suggesting that MEGT may induce apoptosis through increasing intracellular ROS and GSH depletion.

In addition, mitochondria also play an important role in ROS and apoptotic events [61]. For example, capsaicin, the main capsaicinoid found in chili peppers, was found to disrupt mitochondrial membrane potential (MMP) and mediate oxidative stress leading to apoptosis in pancreatic cancer cells [62]. Mitomycin c can kill the small cell lung cancer cells by increasing MMP and decreasing intracellular GSH contents due to oxidative stress [63]. The current study demonstrated that MEGT significantly decreased the MMP in oral cancer cells in a dose-response manner, suggesting that MEGT-induced MMP disruption ability may be directly or indirectly influencing ROS generation in oral cancer cells.

Extracts derived from natural products isolated by different solvents may have different cytotoxic efficacies. For example, the $\mathrm{IC}_{50}$ value of ethanol extract of $G$. tenuistipitata in Ca9-22 cells was 8-fold higher than that of the methanol extract (data not shown), whereas the water extract of G. tenuistipitata did not display any cytotoxicity to H1299 cells [25]. Therefore, methanol extracts of G. tenuistipitata were chosen in this study. Although our results have demonstrated the anti-proliferative effect of MEGT on oral cancer cells, there are some limitations in this study. For example, it has been reported that the polysaccharides from the G. dura [64], the chemical composition of G. cervicornis [65], and the prostaglandin content of G. verrucosa [66] are subject to seasonal variation. Accordingly, the possibility of a seasonal variation in the biological effects of MEGT cannot be excluded.

Phenolics are the most abundant secondary metabolites of plants. Methanol is generally efficient for the extraction of lower molecular weight polyphenols [67]. Preliminary analysis indicated that MEGT were rich in polysaccharides and polyphenols (data not shown). The anticancer activities of polyphenols, such as pro-apoptotic and DNA damaging effects have been reported in many literatures [68-71]. Therefore, we expect that the polyphenols are the candidates for the active principles in MEGT which warrants further investigation.

\section{Conclusion}

In this study, the effects of MEGT on an oral cancer cell model were assayed to explore the genotoxic effect, by cell cycle distribution and annexin $\mathrm{V}$ detection to explore its apoptotic effect, by $\gamma$-H2AX detection to explore its DNA damage effect, by determination of ROS and GSH levels to explore its oxidative stress modifying effect, and by $\mathrm{DiOC}_{2}(3)$ staining to explore the MMP depolarization. The results of this study have demonstrated that MEGT induced potent anti-oral cancer effects thought the induction of apoptosis, DNA damage, and oxidative stress pathways. Based on this finding, MEGT may be a potential natural product for anti-oral cancer treatment.

\section{Competing interests}

The authors declare that they have no competing interests.

\section{Authors' contributions}

C-CY and Y-CC carried out all cell-based experiments. J-IY provided the sample collection and advised C-CY for technical support on extraction. J-CL, C-NT and Y-CH have made substantial contributions to conception and designed the study. C-CY, C-NT, and H-WC drafted the manuscript. J-YT and L-YC performed data analysis. H-WH performed statistical analysis. F-RC and H-WC coordinated, oversaw the study and revised it critically for important intellectual content and corresponding authors. All authors read and approved the final manuscript. 


\section{Acknowledgement}

We thank the National Science Council of Taiwan for grants (NSC98-2314-B037-035), grants for DOH101-TD-C-111-002, Kaohsiung Medical University Research Foundation (KMUER014 and KMU-M110001), and NSYSU-KMU JOINT RESEARCH PROJECT (\#NSYSUKMU 101-006). We also thank Mr. Harrison Yang for English editing.

\section{Author details}

${ }^{1}$ Graduate Institute of Natural Products, College of Pharmacy, Kaohsiung Medical University, Kaohsiung, Taiwan. ${ }^{2}$ Department of Seafood Science, National Kaohsiung Marine University, Kaohsiung, Taiwan. ${ }^{3}$ Department of Biotechnology, Kaohsiung Medical University, Kaohsiung, Taiwan. ${ }^{4}$ Department of Biomedical Science and Environmental Biology, Kaohsiung Medical University, Kaohsiung, Taiwan. ${ }^{5}$ Department of Cosmeceutics, College of Pharmacy, China Medical University, Taichung, Taiwan. ${ }^{6}$ Department of Radiation Oncology, Faculty of Medicine, College of Medicine, Kaohsiung Medical University, Kaohsiung, Taiwan. ${ }^{7}$ Department of Radiation Oncology, Kaohsiung Medical University Hospital, Kaohsiung, Taiwan. ${ }^{8}$ Department of Chemical Engineering, I-Shou University, Kaohsiung, Taiwan. ${ }^{9}$ Institute of Biomedical Science, National Sun Yat-Sen University, Kaohsiung, Taiwan. ${ }^{10}$ Center of Excellence for Environmental Medicine, Cancer Center, Kaohsiung Medical University Hospital, Kaohsiung Medical University, Kaohsiung, Taiwan.

Received: 21 February 2012 Accepted: 23 August 2012

Published: 31 August 2012

\section{References}

1. Parkin DM, Laara E, Muir CS: Estimates of the worldwide frequency of sixteen major cancers in 1980. Int J Cancer 1988, 41(2):184-197.

2. Myoung $H$, Hong SP, Yun PY, Lee JH, Kim MJ: Anti-cancer effect of genistein in oral squamous cell carcinoma with respect to angiogenesis and in vitro invasion. Cancer Sci 2003, 94(2):215-220.

3. Liou KT, Lin SM, Huang SS, Chih CL, Tsai SK: Honokiol ameliorates cerebral infarction from ischemia-reperfusion injury in rats. Planta Med 2003, 69 (2):130-134

4. Jimenez-Medina E, Garcia-Lora A, Paco L, Algarra I, Collado A, Garrido F: A new extract of the plant Calendula officinalis produces a dual in vitro effect: cytotoxic anti-tumor activity and lymphocyte activation. BMC Cancer 2006, 6:119.

5. Koppikar SJ, Choudhari AS, Suryavanshi SA, Kumari S, Chattopadhyay S, Kaul-Ghanekar R: Aqueous cinnamon extract (ACE-c) from the bark of Cinnamomum cassia causes apoptosis in human cervical cancer cell line ( $\mathrm{SiHa}$ ) through loss of mitochondrial membrane potential. BMC Cancer 2010, 10:210.

6. Lee do K, Jang S, Kim MJ, Kim JH, Chung MJ, Kim KJ, Ha NJ: Antiproliferative effects of Bifidobacterium adolescentis SPM0212 extract on human colon cancer cell lines. BMC Cancer 2008, 8:310.

7. Stingl JC, Ettrich T, Muche R, Wiedom M, Brockmoller J, Seeringer A Seufferlein T: Protocol for minimizing the risk of metachronous adenomas of the colorectum with green tea extract (MIRACLE): a randomised controlled trial of green tea extract versus placebo for nutriprevention of metachronous colon adenomas in the elderly population. BMC Cancer 2011, 11:360.

8. Yen CY, Chiu CC, Chang FR, Chen JY, Hwang CC, Hseu YC, Yang HL, Lee AY, Tsai MT, Guo ZL, et al: 4beta-Hydroxywithanolide E from Physalis peruviana (golden berry) inhibits growth of human lung cancer cells through DNA damage, apoptosis and G2/M arrest. BMC Cancer 2010, 10:46.

9. Molinski T: Marine natural products. Clinical advances in hematology \& oncology: H\&O 2009, 7(6):383-385.

10. Molinski TF, Dalisay DS, Lievens SL, Saludes JP: Drug development from marine natural products. Nat Rev Drug Discov 2009, 8(1):69-85.

11. Glaser KB, Mayer AM: A renaissance in marine pharmacology: from preclinical curiosity to clinical reality. Biochem Pharmacol 2009, 78(5):440-448.

12. Mayer AM, Glaser KB, Cuevas C, Jacobs RS, Kem W, Little RD, Mclntosh JM, Newman DJ, Potts BC, Shuster DE: The odyssey of marine pharmaceuticals: a current pipeline perspective. Trends Pharmaco/ Sci 2010, 31(6):255-265.

13. Faulkner DJ: Marine natural products. Nat Prod Rep 2002, 19(1):1-48.

14. Liu M, Hansen PE, Lin X: Bromophenols in marine algae and their bioactivities. Mar Drugs 2011, 9(7):1273-1292.
15. Jha RK, Zi-rong X: Biomedical compounds from marine organisms. Mar Drugs 2004, 2:123-146.

16. Armisen R: World-wide use and importance of Gracilaria. J Appl Phycol 1995, 7:231-243.

17. de Almeida CL, Falcao Hde S, Lima GR, Montenegro Cde A, Lira NS, de Athayde-Filho PF, Rodrigues LC, de Souza Mde F, Barbosa-Filho JM, Batista LM: Bioactivities from marine algae of the genus gracilaria. Int J Mol Sci 2011, 12(7):4550-4573.

18. Lin YH, Tsai JS, Hung LB, Pan BS: Hypocholesterolemic effect of compounded freshwater clam protein hydrolysate and Gracilaria. Food Chemistry 2010, 123:395-399.

19. Yangthong $M$, Hutadilok-Towatana N, Phromkunthong W: Antioxidant activities of four edible seaweeds from the southern coast of Thailand. Plant Foods Hum Nutr 2009, 64(3):218-223.

20. Yeh ST, Lin YC, Huang CL, Chen JC: White shrimp Litopenaeus vannamei that received the hot-water extract of Gracilaria tenuistipitata showed protective innate immunity and up-regulation of gene expressions after low-salinity stress. Fish Shellfish Immunol 2010, 28(5-6):887-894.

21. Ganesan P, Kumar CS, Bhaskar N: Antioxidant properties of methanol extract and its solvent fractions obtained from selected Indian red seaweeds. Bioresour Technol 2008, 99(8):2717-2723.

22. Vijayavel K, Martinez JA: In vitro antioxidant and antimicrobial activities of two Hawaiian marine Limu: Ulva fasciata (Chlorophyta) and Gracilaria salicornia (Rhodophyta). J Med Food 2010, 13(6):1494-1499.

23. Souza BW, Cerqueira MA, Martins JT, Quintas MA, Ferreira AC, Teixeira JA, Vicente AA: Antioxidant potential of two red seaweeds from the Brazilian coasts. J Agric Food Chem 2011, 59(10):5589-5594.

24. Ajisaka T, Chiang YM: Recent status of Gracilaria cultivation in Taiwan. Hydrobiologia 1993, 260/261:335-338.

25. Yang Jl, Yeh CC, Lee JC, Yi SC, Huang HW, Tseng CN, Chang HW: Aqueous extracts of the edible Gracilaria tenuistipitata are protective against $\mathrm{H}_{2} \mathrm{O}_{2}$-induced DNA damage, growth inhibition, and cell cycle arrest. Molecules 2012, 17(6):7241-7254.

26. Bolling BW, Blumberg JB, Chen CY: Extraction methods determine the antioxidant capacity and induction of quinone reductase by soy products in vitro. Food Chem 2009, 116(1):351-355.

27. Rao AS, Reddy SG, Babu PP, Reddy AR: The antioxidant and antiproliferative activities of methanolic extracts from Njavara rice bran. BMC Complement Altern Med 2010, 10:4

28. Rejiya CS, Cibin TR, Abraham A: Leaves of Cassia tora as a novel cancer therapeutic-an in vitro study. Toxicol In Vitro 2009, 23(6):1034-1038.

29. Fares R, Bazzi S, Baydoun SE, Abdel-Massih RM: The antioxidant and antiproliferative activity of the Lebanese Olea europaea extract. Plant Foods Hum Nutr 2011, 66(1):58-63.

30. Kim JY, Yoon MY, Cha MR, Hwang JH, Park E, Choi SU, Park HR, Hwang YI: Methanolic extracts of Plocamium telfairiae induce cytotoxicity and caspase-dependent apoptosis in HT-29 human colon carcinoma cells. $J$ Med Food 2007, 10(4):587-593.

31. Kumar RS, Rajkapoor B, Perumal P: Antitumor and cytotoxic activities of methanol extract of Indigofera linnaei Ali. Asian Pac J Cancer Prev 2011, 12 (3):613-618

32. Matsumoto K, Nakamura T, Kramer RH: Hepatocyte growth factor/scatter factor induces tyrosine phosphorylation of focal adhesion kinase (p125FAK) and promotes migration and invasion by oral squamous cell carcinoma cells. J Biol Chem 1994, 269(50):31807-31813.

33. Sato F, Wu Y, Bhawal UK, Liu Y, Imaizumi T, Morohashi S, Kato Y, Kijima H: PERIOD1 (PER1) has anti-apoptotic effects, and PER3 has pro-apoptotic effects during cisplatin (CDDP) treatment in human gingival cancer CA922 cells. Eur J Cancer 2011, 47(11):1747-1758.

34. Liu C, Tsai AL, Chen YC, Fan SC, Huang CH, Wu CC, Chang CH: Facilitation of human osteoblast apoptosis by sulindac and indomethacin under hypoxic injury. J Cell Biochem 2012, 113(1):148-155.

35. Chiu CC, Liu PL, Huang K, Wang HM, Chang KF, Chou CK, Chang FR, Chong IW, Fang K, Chen JS, et al: Goniothalamin inhibits growth of human lung cancer cells through DNA damage, apoptosis, and reduced migration ability. J Agric Food Chem 2011, 59(8):4288-4293.

36. Wang H, Joseph JA: Quantifying cellular oxidative stress by dichlorofluorescein assay using microplate reader. Free Radic Biol Med 1999, 27(5-6):612-616. 
37. Vermund H, Gollin FF: Mechanisms of action of radiotherapy and chemotherapeutic adjuvants. A review. Cancer 1968, 21(1):58-76.

38. Sun SY, Hail N Jr, Lotan R: Apoptosis as a novel target for cancer chemoprevention. J Natl Cancer Inst 2004, 96(9):662-672.

39. Azuma M, Tamatani T, Ashida Y, Takashima R, Harada K, Sato M: Cisplatin induces apoptosis in oral squamous carcinoma cells by the mitochondria-mediated but not the NF-kappaB-suppressed pathway. Oral Oncol 2003, 39(3):282-289.

40. Yoneda K, Yamamoto T, Osaki T: p53- and p21-independent apoptosis of squamous cell carcinoma cells induced by 5 -fluorouracil and radiation. Oral Oncol 1998, 34(6):529-537.

41. Abal M, Andreu JM, Barasoain I: Taxanes: microtubule and centrosome targets, and cell cycle dependent mechanisms of action. Curr Cancer Drug Targets 2003, 3(3):193-203.

42. Ferreira CG, Epping M, Kruyt FA, Giaccone G: Apoptosis: target of cancer therapy. Clin Cancer Res 2002, 8(7):2024-2034.

43. Malaguarnera L: Implications of apoptosis regulators in tumorigenesis. Cancer Metastasis Rev 2004, 23(3-4):367-387.

44. Luqmani YA: Mechanisms of drug resistance in cancer chemotherapy. Med Princ Pract 2005, 14(Suppl 1):35-48

45. Shoemaker $\mathrm{RH}$ : The $\mathrm{NCl60}$ human tumour cell line anticancer drug screen. Nat Rev Cancer 2006, 6(10):813-823.

46. Sreelatha S, Jeyachitra A, Padma PR: Antiproliferation and induction of apoptosis by Moringa oleifera leaf extract on human cancer cells. Food Chem Toxicol 2011, 49(6):1270-1275.

47. Wurstle ML, Laussmann MA, Rehm M: The central role of initiator caspase9 in apoptosis signal transduction and the regulation of its activation and activity on the apoptosome. Exp Cell Res 2012, 318(11):1213-1220.

48. Reubold TF, Eschenburg S: A molecular view on signal transduction by the apoptosome. Cell Signal 2012, 24(7):1420-1425.

49. Dickey JS, Redon CE, Nakamura AJ, Baird BJ, Sedelnikova OA, Bonner WM: H2AX: functional roles and potential applications. Chromosoma 2009, 118 (6):683-692.

50. Bekker-Jensen S, Mailand N: Assembly and function of DNA double-strand break repair foci in mammalian cells. DNA Repair (Amst) 2010, 9(12):12191228.

51. Chiu CC, Chang HW, Chuang DW, Chang FR, Chang YC, Cheng YS, Tsai MT, Chen WY, Lee SS, Wang CK, et al: Fern plant-derived protoapigenone leads to DNA damage, apoptosis, and $\mathrm{G}(2) / \mathrm{m}$ arrest in lung cancer cell line H1299. DNA Cell Biol 2009, 28(10):501-506.

52. Kang MA, So EY, Simons AL, Spitz DR, Ouchi T: DNA damage induces reactive oxygen species generation through the $\mathrm{H} 2 \mathrm{AX}$-Nox1/Rac1 pathway. Cell Death Dis 2012, 3:e249.

53. Hamanaka RB, Chandel NS: Mitochondrial reactive oxygen species regulate cellular signaling and dictate biological outcomes. Trends in biochemical sciences 2010, 35(9):505-513.

54. Simon HU, Haj-Yehia A, Levi-Schaffer F: Role of reactive oxygen species (ROS) in apoptosis induction. Apoptosis 2000, 5(5):415-418.

55. Shackelford RE, Kaufmann WK, Paules RS: Oxidative stress and cell cycle checkpoint function. Free Radic Biol Med 2000, 28(9):1387-1404.

56. Ding H, Han C, Guo D, Chin YW, Ding Y, Kinghorn AD, D'Ambrosio SM: Selective induction of apoptosis of human oral cancer cell lines by avocado extracts via a ROS-mediated mechanism. Nutr Cancer 2009, 61 (3):348-356

57. Jeong JC, Jang SW, Kim TH, Kwon CH, Kim YK: Mulberry fruit (Moris fructus) extracts induce human glioma cell death in vitro through ROSdependent mitochondrial pathway and inhibits glioma tumor growth in vivo. Nutr Cancer 2010, 62(3):402-412.

58. Bechelli J, Coppage M, Rosell K, Liesveld J: Cytotoxicity of algae extracts on normal and malignant cells. Leukemia Research and Treatment 2011, Article ID 373519:1-7.

59. Matthews GM, Howarth GS, Butler RN: Nutrient and antioxidant modulation of apoptosis in gastric and colon cancer cells. Cancer Biol Ther 2006, 5(6):569-572.

60. Higuchi Y: Glutathione depletion-induced chromosomal DNA fragmentation associated with apoptosis and necrosis. J Cell Mol Med 2004, 8(4):455-464

61. Kowaltowski AJ, de Souza-Pinto NC, Castilho RF, Vercesi AE: Mitochondria and reactive oxygen species. Free Radic Biol Med 2009, 47(4):333-343.

62. Pramanik KC, Boreddy SR, Srivastava SK: Role of mitochondrial electron transport chain complexes in capsaicin mediated oxidative stress leading to apoptosis in pancreatic cancer cells. PLoS One 2011, 6(5): e20151.

63. Lee CS, Park SY, Ko HH, Han ES: Effect of change in cellular GSH levels on mitochondrial damage and cell viability loss due to mitomycin c in small cell lung cancer cells. Biochem Pharmacol 2004, 68(9):1857-1867.

64. Marinho-Soriano E, Bourret E: Polysaccharides from the red seaweed Gracilaria dura (Gracilariales, Rhodophyta). Bioresour Technol 2005, 96 (3):379-382.

65. Marinho-Soriano E, Fonseca PC, Carneiro MA, Moreira WS: Seasonal variation in the chemical composition of two tropical seaweeds. Bioresour Technol 2006, 97(18):2402-2406.

66. Imbs AB, Vologodskaya AV, Nevshupova NV, Khotimchenko SV, Titlyanov EA: Response of prostaglandin content in the red alga Gracilaria verrucosa to season and solar irradiance. Phytochemistry 2001, 58(7):1067-1072.

67. Dai J, Mumper RJ: Plant phenolics: extraction, analysis and their antioxidant and anticancer properties. Molecules 2010, 15(10):7313-7352.

68. Lamoral-Theys D, Pottier L, Dufrasne F, Neve J, Dubois J, Kornienko A, Kiss R, Ingrassia L: Natural polyphenols that display anticancer properties through inhibition of kinase activity. Curr Med Chem 2010, 17(9):812-825.

69. Hu ML: Dietary polyphenols as antioxidants and anticancer agents: more questions than answers. Chang Gung medical journal 2011, 34(5):449-460.

70. Guo W, Kong E, Meydani M: Dietary polyphenols, inflammation, and cancer. Nutr Cancer 2009, 61(6):807-810.

71. Hadi SM, Bhat SH, Azmi AS, Hanif S, Shamim U, Ullah MF: Oxidative breakage of cellular DNA by plant polyphenols: a putative mechanism for anticancer properties. Semin Cancer Biol 2007, 17(5):370-376.

doi:10.1186/1472-6882-12-142

Cite this article as: Yeh et al:: Anti-proliferative effect of methanolic extract of Gracilaria tenuistipitata on oral cancer cells involves apoptosis, DNA damage, and oxidative stress. BMC Complementary and Alternative Medicine 2012 12:142.

\section{Submit your next manuscript to BioMed Central and take full advantage of:}

- Convenient online submission

- Thorough peer review

- No space constraints or color figure charges

- Immediate publication on acceptance

- Inclusion in PubMed, CAS, Scopus and Google Scholar

- Research which is freely available for redistribution
C) Biomed Central 